\title{
Protein Sparing Effects of Lipids in The Practical Diets of Oreochromis niloticus (Nile tilapia)
}

\author{
*A.M. Orire and S.O.E. Sadiku \\ Department of Water Resources, Aquaculture and Fisheries Technology \\ Federal University of Technology, P.M.B 65, Minna, Niger State-Nigeria. \\ [Corresponding Author: E-mail: Orire9@yahoo.com; Tel.: +234-70325595]
}

\begin{abstract}
A feeding trial was conducted to establish the protein sparing effects of various lipid sources in Oreochromis niloticus fingerlings (mean weight $8.05 \pm 0.05 \mathrm{~g}$ ) for 8 weeks. Nine experimental diets and one commercial reference diet was used for the trial. The experimental diets comprised of three levels of lipid $(\mathrm{L})$ and protein $(\mathrm{P})$ designated as $15 \mathrm{P}: 25 \mathrm{~L}, 10 \mathrm{P}: 30 \mathrm{~L}$ and $5 \mathrm{P}: 35 \mathrm{~L}$ ratios. Three lipid sources used were groundnut oil, palm oil and fish oil. The result obtained showed significant differences $(\mathrm{P}<0.05)$ among the lipid sources. Fish oil showed significant differences in the mean weight gain (MWG), specific growth rate (SGR), feed conversion rate (FCR), and apparent net protein utilization (ANPU) for all the treatments. The carcass compositions was also significant $(\mathrm{P}<0.05)$ in moisture, lipid and ash which resulted in protein sparing at $10 \%$ inclusion level thereby bringing down crude protein inclusion level to $30 \%$. Groundnut oil did not show significant difference $(\mathrm{P}>0.05)$ in the MWG, and SGR for all the treatments, but showed significant difference $(\mathrm{P}<0.05)$ for the FCRs, PERs and ANPUs. The palm oil based diets also gave significant difference $(\mathrm{P}<0.05)$ in the MWG, SGR, PER and ANPU. There was significant difference $(\mathrm{P}<0.05)$ in the carcass compositions. Groundnut oil was observed to spare protein at $10 \%$ inclusion level while palm oil spared same at $15 \%$ inclusion level. These findings will ensure reduction in the crude protein inclusion level in the diets of $O$. niloticus using these lipid sources.
\end{abstract}

\section{INTRODUCTION}

The imperative need to reduce feed cost in aquaculture has been reported (Jauncey, 1998; Peres and Oliva-Teles, 2002; Jamu and Ayinla, 2003; Martino et al. 2002). The protein component of feed is responsible for its high cost (Shiau and Lin, 1993) and most especially fishmeal (NRC, 1993). Thus, efficient transformation of protein into tissue protein for growth is of immense significance (Weatherly and Gill, 1987). Furthermore, metabolization of protein by fish should be directed towards body protein synthesis rather than energy supply (Shiau, 1997; Borba et al. 2006). Growth rates of fish may be highly variable and, in many cases, appear to be limited by food availability, quality and quantity of dietary non-protein to protein nutrients. In hybrid tilapia (Oreochromis niloticus $x O$. aureus), optimum dietary lipid for maximum growth has been reported to be about 12\% (Chou and Shiau, 1999). However, Tilapia has been reported to utilize vegetable oil that is high in omega $6(n-6)$ fatty acids better than fish oil that is rich in omega 3 (n-3) fatty acids for maximum growth (NRC, 1993). Although the available dietary energy plays an important role in determining body lipid deposition, the dietary lipid content is regarded as the most important factor influencing carcass lipid in fish (Sargent et al., 1989; Hanley, 1991). An increase in dietary lipid level elevates the body lipid level in $O$. niloticus. The increase in carcass lipids with increasing dietary lipids and the consequent reduction in carcass proteins have been reported for most species investigated (Refstie and Austreng, 1981; De-Silva et al., 1991). The authors suggested that Tilapia do not utilize the additional energy provided by the supplementary dietary lipid (over 5\%) for growth. The objective of the present study was to examine the protein sparing effects of lipids in $O$. niloticus.

\section{MATERIALS AND METHODS}

Experimental System: The study was conducted in a recycling water system of the Department of Water Resources, Aquaculture and Fisheries Technology, School of Agriculture and Agricultural Technology, Federal University of Technology, Minna. Ten-week old $(8.05 \pm 0.05 \mathrm{~g})$ fingerlings of $O$. niloticus were obtained from the 
hatchery unit of National Institute of Freshwater Fisheries Research (NIFFR), NewBussa, Niger State. The fishes were randomly assigned into groups of 15 fishes per tank and each group was placed in an individual 50-L cylindrical tank.

\section{Experimental Diets}

Nine experimental diets and one commercial reference diet [(CRD) - Coppens Catfish feed from Netherland)] were used for the feeding trial. The experimental diets were formulated using equational method of two unknowns. The diets were formulated to contain three levels of protein $(\mathrm{P})$ and three levels of lipid $(\mathrm{L})$ ratios $(15 \mathrm{P}: 25 \mathrm{~L}$, 10P : 30L and 5P : 35L \%), using three lipid sources; Fish oil, Palm oil and Groundnut oil and Fishmeal as protein source. The experimental design $3 \times 3$ factorial of completely randomized design (CRD). The table of formulation and its proximate analysis is shown in Table 1 . The fishes were fed twice daily between the hours 10.00 and 16.00 to apparent satiation for 8 weeks.

\section{Experimental Analyses and Growth} Parameters: Proximate analysis for moisture, crude protein, crude lipid and ash of carcass, feed ingredients and experimental diets were determined according to the methods of AOAC (2000). Final values for each group represent the arithmetic mean of the triplicates. Feed intake was monitored to measure average feed intake and their effects on growth. The growth and nutrient utilization parameters measured include weight gain, specific growth rate (SGR), feed conversion ratio (FCR), protein efficiency ratio (PER), apparent net protein utilization (ANPU). The growth parameters were computed as stated below;

Mean weight gain $=$ Mean final weight $\ddot{i}$ mean initial weight

Specific Growth Rate $(\mathrm{SGR})=\frac{\left(\log _{\mathrm{e}} \mathrm{W}_{2}-\log _{\mathrm{e}} \mathrm{W}_{1}\right)}{\mathrm{T}_{2} \ddot{\mathrm{I}} \mathrm{T}_{1}} \times 100$

Where, $W_{2}$ and $W_{1}$ represent $\ddot{i}$ final and initial weight,

$\mathrm{T}_{2}$ and $\mathrm{T}_{1}$ represent $i ̈$ final and initial time

Feed conversion ratio $\ddot{i}$ Feed fed on dry matter/fish live weight gain

Protein efficiency ratio $($ PER) $=$ Mean weight gain per protein fed

Protein intake $(\mathrm{g})=$ Feed intake $\mathrm{x}$ crude protein of feed.
Apparent net protein utilization $($ ANPU \% $)=(\mathrm{P} 2$ - P1) / Total protein consumed (g) X $\square 100$

Where, $\mathrm{P} 1$ is the protein in fish carcass $(\mathrm{g})$ at the beginning of the study and $\mathrm{P} 2$ is the protein in fish carcass $(\mathrm{g})$ at the end of the study.

Statistical analysis: The experimental design was factorial and the data was subjected to one way analysis of variance to test their significant levels at $5 \%$ probability, the means were separated using Tukeyôs method and the regression coefficients were analysed using Minitab Release 14 while the graphs were drawn using the Microsoft excel window 2007.

\section{RESULTS}

The diet formulation and proximate analysis are presented in Table 1. The results of growth and feed performance of $O$. niloticus fed different sources of lipids at different levels of crude protein are presented in Tables 2 and 3. The diets were accepted by the fishes throughout the experiment. The growth performances were significantly $(\mathrm{P}<0.05)$ affected by the levels of protein and lipids in the diets.

Groundnut oil (GO) based diets: There was significant difference $(\mathrm{P}<0.05)$ in the utilization of groundnut oil $(\mathrm{GO})$ as dietary lipid source for the growth of $O$. niloticus at different $\mathrm{L} / \mathrm{P}$ ratios. However, there were no significant differences $(\mathrm{P}>0.05)$ in the mean weight gains (MWG) and specific growth rate (SGR) and the feed conversion rate (FCR) for the three L/P ratios fed (Table 2). There were no significant differences $(\mathrm{P}>0.05)$ in the $\mathrm{PER}$ values for $\mathrm{L} / \mathrm{P}$ ratios $10: 30$ $(0.87)$ and 5:35 (0.91) respectively. However, the ANPU values was significant $(\mathrm{P}<0.05)$ for $\mathrm{L} / \mathrm{P}$ ratio 15:25 which gave the highest value (72.67) followed by $5: 35(53.32)$ while the $10: 30 \mathrm{~L} / \mathrm{P}$ ratio gave the lowest value (9.09) (Table 2). The body protein value was significantly high for 15 : 25 and 5 : 35 without significant difference $(\mathrm{P}>0.05)$ between the treatments. Furthermore, diet containing L/P ratio of $10: 30$ had the highest lipid, ash and moisture contents (Table 3). The survival rate was highest for $5: 30(96.67 \%) \mathrm{L} / \mathrm{P}$ ratio and lowest for $15: 25$ (70.67\%) (Table 2). 
Palm oil based diets: Palm oil based diets also showed significant difference $(\mathrm{P}<0.05)$ for all the treatments in the growth performance (Table 2). The $\mathrm{L} / \mathrm{P}$ ratio of 10: 30 gave the highest MWG, SGR and PER (2.86, 0.51, 4.28 respectively). The ANPU was highest for $15: 25$ (68.94) followed by $10: 30(50.30)$ while $5: 35$ gave the least value of 2.98 . The body protein was slightly significantly $(\mathrm{P}<0.05)$ lower than the $\mathrm{L} / \mathrm{P}$ ratio of 15: 35. The $\mathrm{L} / \mathrm{P}$ ratio for 15: 35 also gave significantly $(\mathrm{P}<0.05)$ high body lipid and ash than other $\mathrm{L} / \mathrm{P}$ ratios but has lowest moisture percentage (Table 3). The survival percentage was highest for L/P ratio 5: $35(90.00 \%)$ and lowest with diet containing L/P ratio 10: 30 (56.67 \%) (Table 2).

Fish oil based diets: Diet containing 10:30 L/P ratio gave the highest $\mathrm{MWG}$, SGR, PER and lowest FCR but significantly low ANPU value (14.44) (Table 4.3.3). However, the ash and moisture contents of 10: 30 were significantly higher $(\mathrm{P}<0.05)$ than diets of other $\mathrm{L} / \mathrm{P}$ ratios. The $\mathrm{L} / \mathrm{P}$ ratio $5: 30$ diets perform efficiently better than $\mathrm{L} / \mathrm{P}$ ratio of $15: 25$ diets, however, the ANPU value for diet containing $15: 25$ was significantly higher $(\mathrm{P}<0.05)$ than that of $5: 35$ $\mathrm{L} / \mathrm{P}$ ratio whose body lipid and ash were equally significantly lower $(\mathrm{P}<0.05)$ as shown in Table 3. The survival rate was significantly higher $(\mathrm{P}<0.05)$ for diets containing L/P ratios 15:25 and $5: 35$ (93.33\% respectively) (Table 2 ).

Growth response: The growth response as shown in Figures 1-3 indicated protein sparing effects of lipids in $O$. niloticus. The groundnut oil based diets exhibited a bundle growth response, a situation where all the treatments exhibited same trend of growth pattern almost throughout the feeding trial. The palm oil and fish oil based diets also showed similar growth pattern to that of groundnut oil but at the $8^{\text {th }}$ week palm oil protein sparing appears to arise.

\section{DISCUSSION}

The results showed that Groundnut oil was efficiently utilized for growth at all levels of inclusions as observed in the growth curve (Figure 1), however, the growth performance at 5:30 lipid/protein (L/P) ratio gave a better growth performance than other ratios. The lipid inclusion level at $10 \%$ would have been best if not for the low apparent net protein utilization (ANPU) value recorded. The low ANPU indicated that the high lipid level was not utilized for tissue development as evident in the carcass lipid (Table 3). The L/P ratio at $15: 25$ even though has low MWG and SGR values gave the highest ANPU value.

The Palm oil based diets were also utilized by $O$. niloticus. The mean weight gain was highest at lipid level of $10 \%$ and crude protein level of $30 \%$ with high SGR, PER but with low ANPU values. However, when the lipid level was lowered to 5\% and crude protein level increased to $35 \%$, there was decline in growth. Moreover, increasing the dietary lipid to $15 \%$ while reducing crude protein to $25 \%$, there was efficient utilization of the diets and the nutrients which resulted in lowest FCR value and highest ANPU value. The poor growth performance observed at $\mathrm{L} / \mathrm{P}$ of $5: 35$ indicated inadequate energy level in the diets for the requirement of tilapia. Thereby resulting in the metabolization of crude protein for energy as was evident in the low ANPU value obtained. The L/P ratio at 15:25 indicated nutrient utilization with concomitant increase in the body lipid. At this level of $\mathrm{L} / \mathrm{P}$ ratio, $O$. niloticus appeared to be incapable of utilizing the excess lipid for energy which invariably was deposited. This phenomenon has been reported for several species (Refstie and Austeng, 1981; Sargent et al. 1989; Hanley, 1991). Similarly, DeSilva et al. 1991 also stated that increasing dietary lipid increases body lipid and decreases carcass protein in $O$. niloticus and other species.

The utilization of dietary lipids for energy as nonprotein source is subject to fatty acid component and source of lipid ( $\mathrm{Ng}$ and Cheng, 2006). The results obtained indicated depressed growth in $O$. niloticus fed with fish oil compared with other vegetable oils like groundnut oil and palm oil. Kanazawa et al. (1980) established that Tilapia exhibits depressed growth when its diets is supplemented with 18 : 3n-3 or n-3 highly unsaturated fatty acid (HUFA). $\mathrm{Ng}$ et al. (2001) also reported that hybrid tilapia fed cod liver oil showed significant depressed growth and feed efficiency ratio, which was attributed to high n-3 HUFA in the cod liver oil. However, Chou and Shiau (1996) reported that the optimal dietary 
lipid for the maximum growth of hybrid Tilapia (O. niloticus $x$ O. Aureus) is about $12 \%$.

The low feed and nutrient utilization observed at 5 : $35 \mathrm{~L} / \mathrm{P}$ ratio for all the lipid sources could be attributed to insufficient dietary energy in the diet to meet the energy requirement of the fish. At this instance, the excess protein would be channeled towards energy production (Smith, 2009; Wilson, 1984). This is uneconomical from the production point of view (Borba et al., 2006; Shiau, 1997; Lovell, 1988). The increment of lipid to the highest level of $15 \%$ gave improved performance for all the lipid sources. However, the palm oil based diets had the highest level of utilization than other lipid sources for growth. The efficient utilization of palm oil by fish more than any other vegetable oils has been reported by several authors (Ng and Chong, 2006; Kaushik, 2004, Ng, 2004 and Hardy et al., 1987). The inclusion of dietary palm oil up to $10 \%$ was utilized for energy requirement of the fish, thereby, sparing the available protein for growth.

On the growth response, the groundnut oil based diets exhibited a bundle growth pattern for all the treatments irrespective of levels of lipid-protein inclusion. This trend indicated the ability of $O$. niloticus to utilize vegetable oil of groundnut origin up to $15 \%$ without any negative effects on the growth and health of the fish (Figure 1). This level of lipid actually spared protein for growth thereby allowing for reduction of crude protein level to $25 \%$. The palm oil based diets spared protein for growth at all levels of input up to the $7^{\text {th }}$ week of feeding trial when dietary palm oil level at $10 \%$ began to spare more than other ratios (Figure 2). The capability of tilapia to utilize palm oil has been reported by $\mathrm{Ng}$ et al. (2001). The reason is attributed to the omega 6 fatty acid in vegetable oil (Okoye et al. 2001). Furthermore, the fish oil based diets optimally spared protein for growth at $10 \%$ inclusion level beyond which there was decline in growth. Huang et al. (1989) reported hybrid tilapia $O$. niloticus $\mathrm{x}$ Oreochroims aureus fingerlings fed $8 \%$ fish oil showed no difference in growth and feed efficiency after 10 weeks on the diets. This observation pointed to the limited ability of tilapia to utilize fish oil over vegetable oil due to the concentration of omega 3 fatty acid in the former (Kanazawa, 1985; Okoye et al. 2001). Furthermore, Aderolu and Akinremi (2009) reported satisfactory diets acceptance at $10 \%$ dietary lipid inclusion levels. Babalola and Adebayo (2007) also reported that Heterobranchus longifilis fingerlings fed graded levels of plant oil up to $12.5 \%$ inclusion level neither showed retarded growth nor feed intake associated problems.

Therefore, in this study, fish oil spared protein for growth at $10 \%$ inclusion dietary inclusion level thereby lowering crude protein to $30 \%$. However, other groundnut oil and palm oil spared protein up to at $10 \%$ and $15 \%$ respectively, thereby lowering the crude protein level to $30 \%$ and $25 \%$.

\section{CONCLUSION}

Findings from the feeding trial showed protein sparing of lipids in $O$. niloticus. The three lipid types tested spared protein for growth at various inclusion levels. 
Table 1: Diets Formulated and their proximate composition

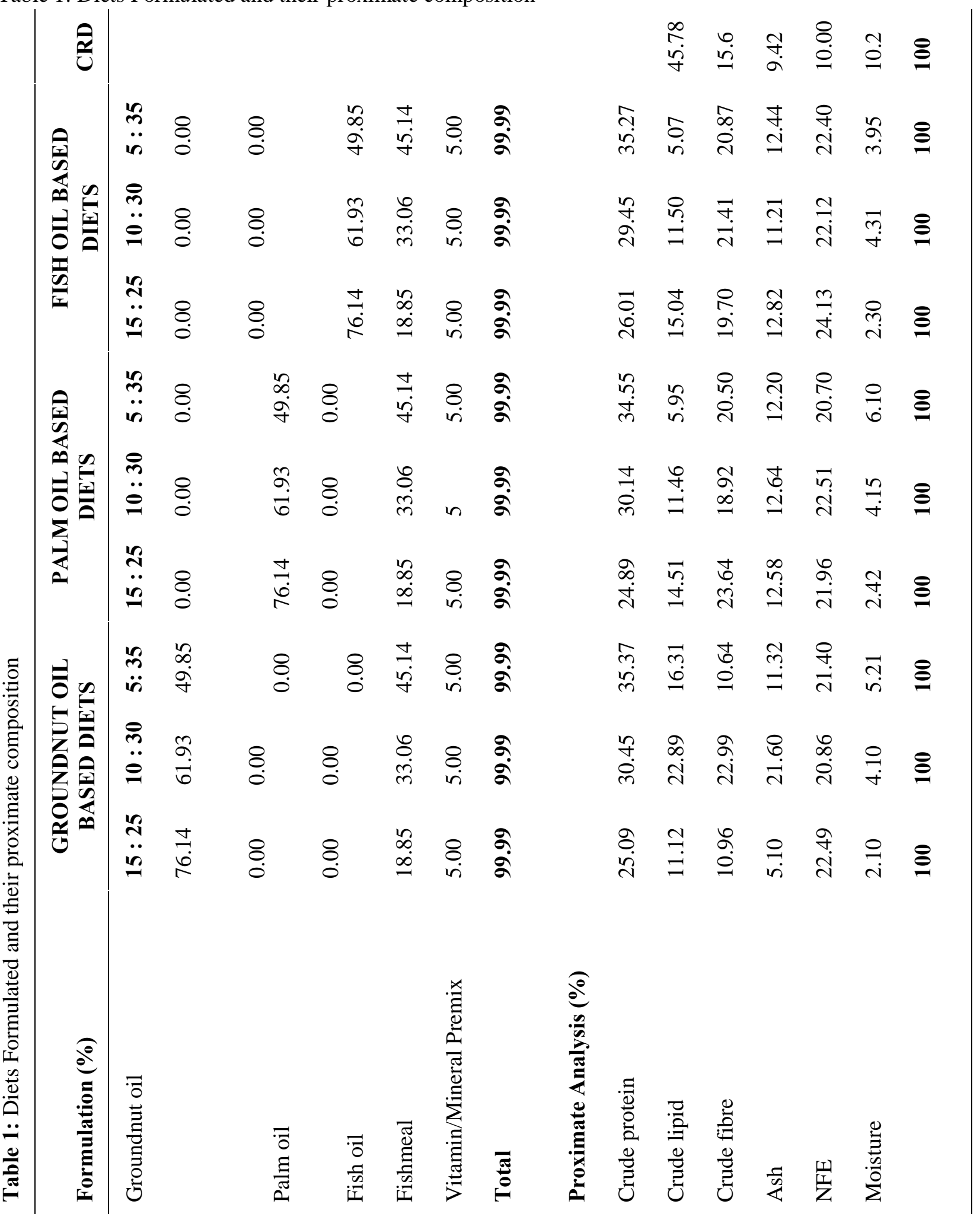


Nigerian Journal of Basic and Applied Science (2011), 19(1):143- 150

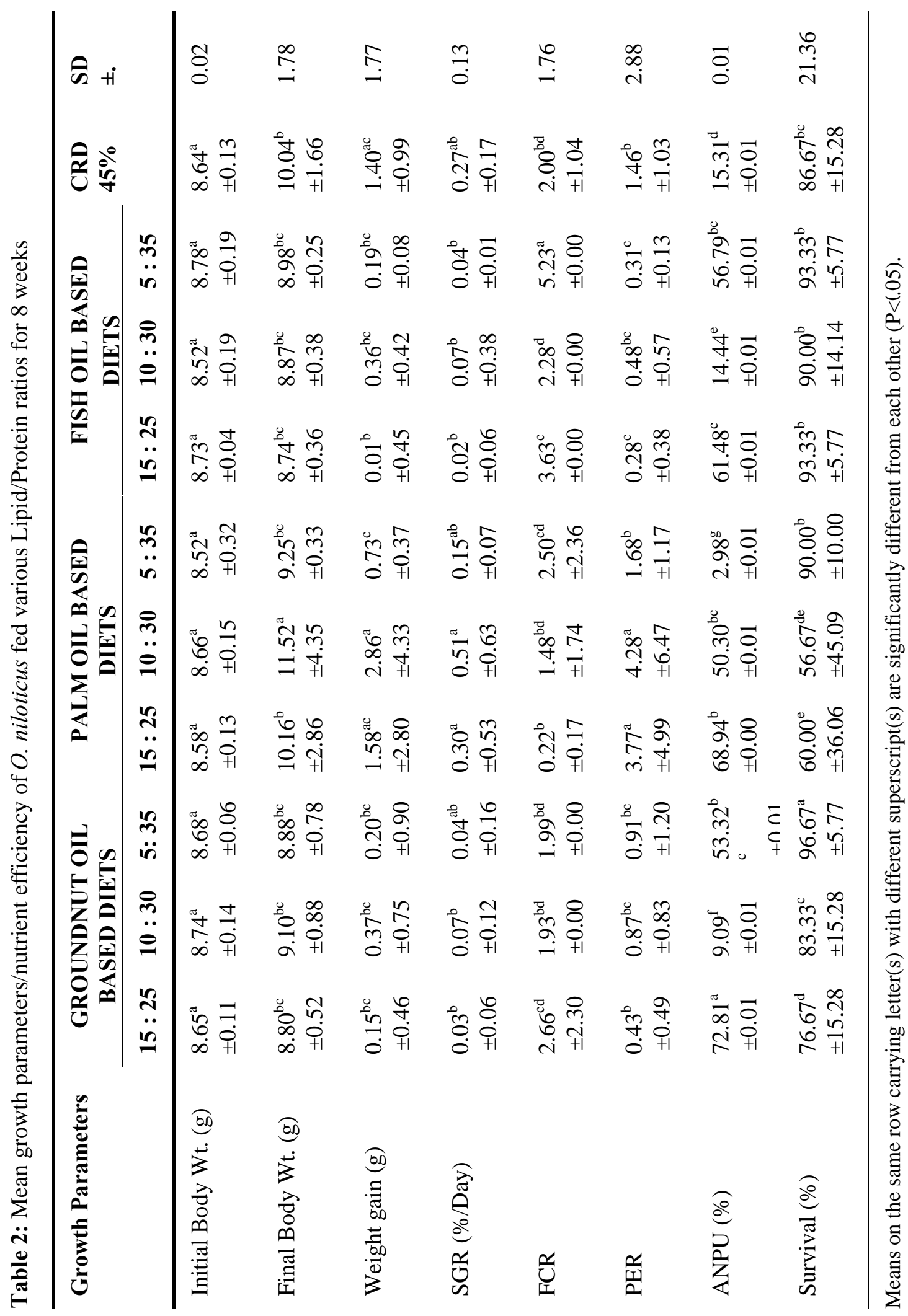




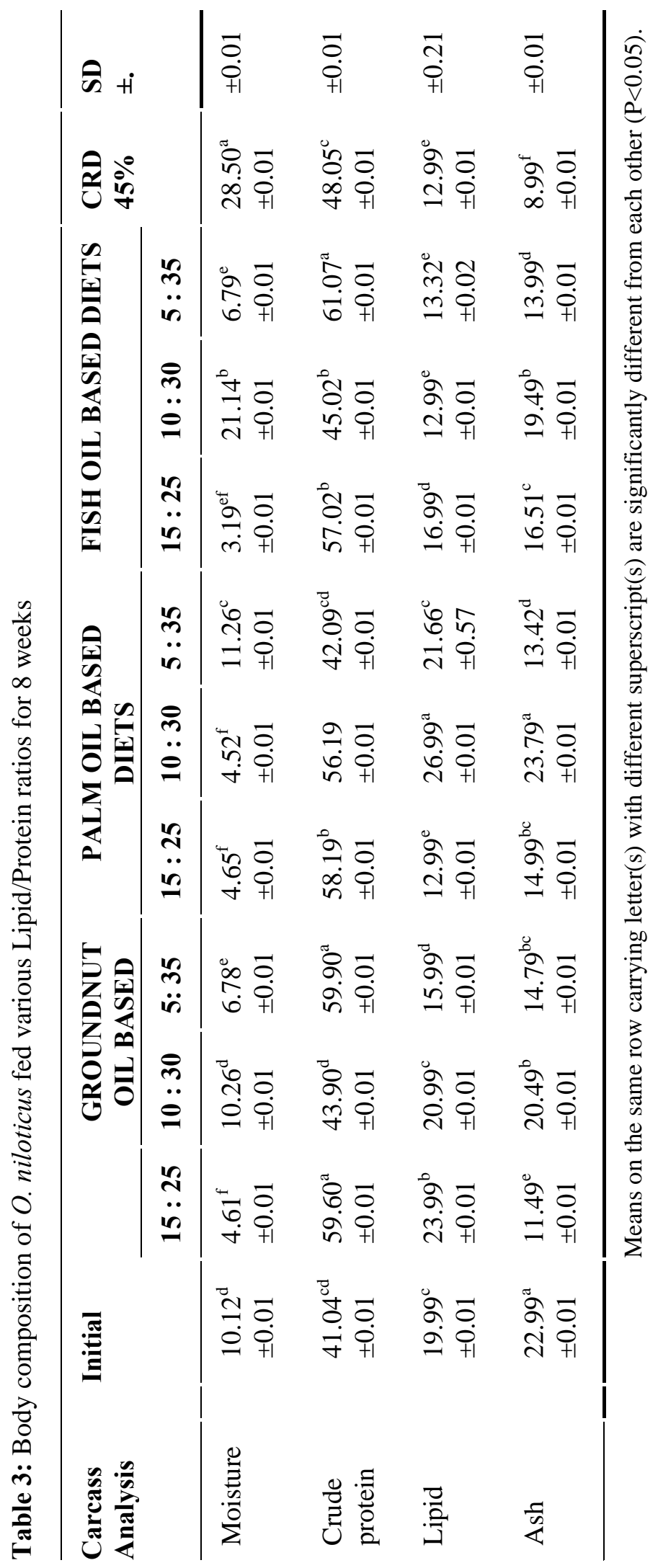




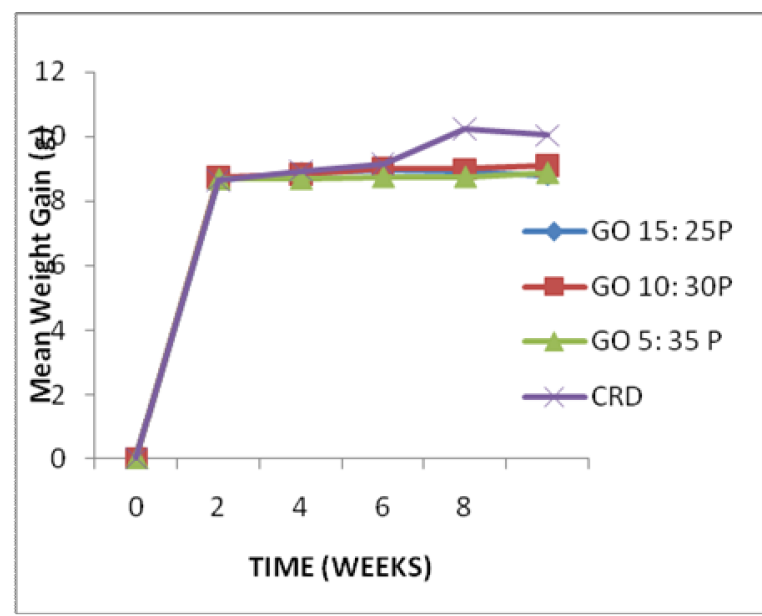

Fig. 1: Growth response of $O$. niloticus fed with Groundnut oil based-diets at different Lipid/Protein ratios for 8 weeks

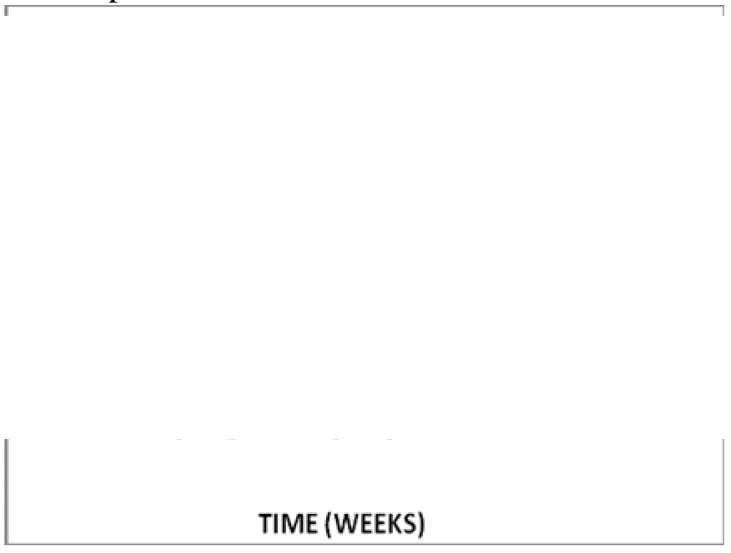

Fig. 2: Growth response of $O$. niloticus fed with Palm oil based-diets at different Lipid/Protein ratios for 8 weeks

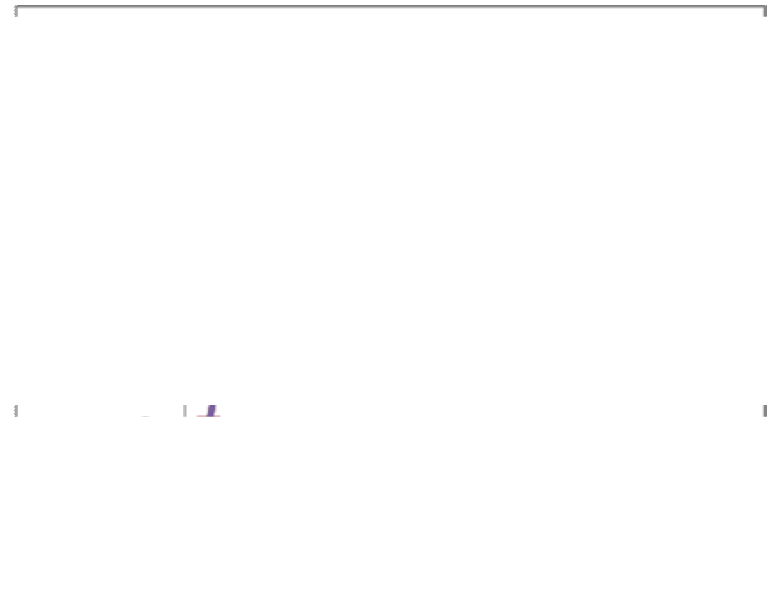

Fig. 3: Growth response of $O$. niloticus fed with Fish oil based-diets at different Lipid/Protein ratios for 8 weeks

\section{REFERENCES}

Aderolu, A.Z. and Akinremi O.A (2009). Dietary effects of coconut oil and peanut oil in improving biochemical characteristics of Clarias gariepinus juvenile. Turkish $J$. Fisheries Aquatic Sci. 9: 105-110.I

Association of Official Analytical Chemists (AOAC) (2000). Official Methods of Analysis. (17th edn., AOAC), Gaithersburg, MD

Babalola, T.O. and Adebayo, M.A. (2007). Effect of dietary lipid level on growth performance and feed utilization by Heterobranchus longifilis fingerlings. J. Fisheries Inter. 2 (1): 60-64.

Borba, D.M, Francalossi, I.E, and Pezzato L.E (2006): Dietary Energy Requirement of Piracanjuba fingerlings, Brycon orbigynanus, and Relative Utilization of Dietary Carbohydrate and Lipid. Aqu. Nutr. 12(3): 183-191Chou, B.S and Shiau, S.Y. (1996). Optimal dietary lipid level for growth of juvenile hybrid tilapia Oreochromis niloticus $x$ Oreochromis aureus. Aquacul. 143:185195.

Chou, B.S. and S.Y. Shiau (1999). Optimal dietary lipid for growth of juvenile hybrid tilapia, Oreochromis niloticus X O. aureus. Aquacul. 43 (2): 185-195.

De-Silva S.S., Guansekera R.M and Shim K.F. (1991). Interactions of varying dietary protein and lipidlevels in young red tilapia : evidence of protein sparing, Aquacul. 95: 305-318.

Hanley, F. (1991). Effects of feeding supplementary deits containing varying levels of lipid on growth, food conversion, body composition of Nile tilapia, Oreochromis niloticus (L.) Aquacul. 93: 323-334.

Hardy, R.W., T.M. Scott and L.W. Harrell. (1987). Replacement of herring oil with menhaden oil, soybean oil, or tallow in the diets of Atlantic salmon raised in marine netpens. Aquacu. 65: 267-277.

Huang, S.S.O., Fynn-Aikins, K.F., Lutes, P.B and Xu, R.P. (1989). Ability of juvenile white sturgeon (Acipenser transmontanus) to utilize different carbohydrate sources. J. Nutr. 119: 727-733. 
Jauncey, K. (1998). Tilapia Feeds and Feeding. Pisces Press Ltd., Stirling, Scotland. 240p.

Jamu D.M.and O.A. Ayinla (2003). Potential for the Development of Aquaculture In Africa. NAGA, World Fish Center Quart. 26(3): 913.

Kanazawa, A. (1985). Essential fatty acids and lipid requirement of fish. In: Nutrition and feeding in fish. Academic Press, London.

Kanazawa, A., Teshima, S., Sakamoto, M. and Awal,M.A (1980). Requirements of Tilapia zilli for essential fatty acids. Bull. Japan Soc. Sci. Fisheries 46: 1353-1356.

Kaushik, S.J. (2004). Fish oil replacement in aquafeeds. Aqua Feeds: Formulation and Beyond 1: 3-6

Lovell, T. (1988). Digestion and metabolism. In: Nutrition and Feeding of fish (ed. By Lovell, T.) Van Nostrand Reinhold, New York.

Martino, R.C., Cyrino, J.E.P. , Portz. , L. and Trugo, L.C (2002). Effect of dietary lipid level on nuirtional performance of the surubim, Pseudoplatystoma coruscans. Aquacul. 209: 209-218

Ng, W.K. (2004). Palm oil as a novel dietary lipid source in aquaculture feeds. Palm Oil Dev. 41: $14-18$.

Ng, W.K., Lim, P.K. and Sidek, H.( 2001). The influence of a dietary lipid source on growth muscle fatty acid composition and erythrocyte osmotic fragility of hybrid tilapia. Fish Physiol. Biochem. 25: 301-310.

National Research Council (NRC) (1993). Nutrent requirement of fish. Committee on Animal Nutrition. Board on Agriculture.National Academy of Sciences. National Academy Press. Washington DC., USA. P. 114.

$\mathrm{Ng}$ W.K. and Cheong-Yew C. (2006). AN Overview of Lipid Nutrition With Emphasis on Alternative Lipid Sources in Tilapia
Feeds. http://ag.arizona.edu/azaqua/ista/ istabweb/pdf/241

Okoye, F.C., EYO, A.A. and Aminu, N.G. (2001). The effect of different lipid sources on the growth and survival of Oreochromis niloticus hybrid fingerlings. Biosci. Res. Comm. 13( 3):

Peres, H. and Olive-Teles, A. (2002). Utilization of raw and gelatinized starch by European sea bass (Dicentrarchus labrax) juveniles. Aquacul. 205: 287-299.

Refstie, T. and Austreng E. (1981). Carbohydrate in rainbow trout diets. III. Growth and chemical composition of fish from different families fed four levels of carbohydrate in the diet, Aquacul. 25: 35-49.1

Sargeant J., Henderson R.J. and Tocher D.R (1989). The lipids, in: Halver J.E. (Ed.), Fish Nutrition, Academic Press. New York, NY, pp. 154-209.

Shiau, S.Y. (1997). Utilization of carbohydrates in warmwater fish $\ddot{i}$ with particular reference to tilapia, Oreochromis niloticus $x$ O. aureus. Aquacul. 151:79-96.

Shiau, S.Y. and Lin, S.F., (1993). Effect of supplementary dietary chromium and vanadium on the utilization of different carbohydrates in tilapia, Oreochromis niloticus x O. aureus. Aquacul. 110: 321330.

Smith, R.R (2009). Nutritional Bioenergetics in Fish FAO Cooperate Document Repository, Fisheries and Agriculture Dept. www.fao.org/docrep 2009.

Weatherley, A.H. and Gill, H.S. (1987). Recovery growth following periods of restricted rations and starvation in rainbow trout, Salmo gairdneri Richardson. J. Fish Bio. 18(2): 195-207.

Wilson, R.P. (1984) Utilization of dietary carbohydrate by fish. Aquacul.124: 67-80. 